LAWRENCE LIVERMORE NATIONAL LABORATORY

\title{
Printed Wiring Board Fabrication and Lead Elimination Via Single-Bath Electrodeposition
}

M. P. Meltzer, C. P. Steffani

February 21, 2001 


\section{DISCLAIMER}

This document was prepared as an account of work sponsored by an agency of the United States Government. Neither the United States Government nor the University of California nor any of their employees, makes any warranty, express or implied, or assumes any legal liability or responsibility for the accuracy, completeness, or usefulness of any information, apparatus, product, or process disclosed, or represents that its use would not infringe privately owned rights. Reference herein to any specific commercial product, process, or service by trade name, trademark, manufacturer, or otherwise, does not necessarily constitute or imply its endorsement, recommendation, or favoring by the United States Government or the University of California. The views and opinions of authors expressed herein do not necessarily state or reflect those of the United States Government or the University of California, and shall not be used for advertising or product endorsement purposes.

This work was performed under the auspices of the U.S. Department of Energy by the University of California, Lawrence Livermore National Laboratory under Contract No. W-7405-Eng-48.

This report has been reproduced directly from the best available copy.

Available to DOE and DOE contractors from the Office of Scientific and Technical Information

P.O. Box 62, Oak Ridge, TN 37831

Prices available from (423) 576-8401 http:/ / apollo.osti.gov/bridge/

Available to the public from the National Technical Information Service

U.S. Department of Commerce 5285 Port Royal Rd., Springfield, VA 22161 http://www.ntis.gov/

OR

Lawrence Livermore National Laboratory Technical Information Department's Digital Library http://www.llnl.gov/tid/Library.html 


\title{
Printed Wiring Board Fabrication and Lead Elimination via Single-Bath Electrodeposition
}

\author{
Principal Investigator: Michael P. Meltzer, Environmental \\ Protection Department, ORAD/PRAG
}

\section{Co-investigator: Christopher P. Steffani, Manufacturing \& Materials Engineering Division}

\author{
Tracking Code: 97-ERD-032
}

Printed wiring board (PWB) fabrication, an operation performed both at LLNL and throughout the electronics industry, generates considerable quantities of hazardous waste, notably lead-bearing materials used for soldering, tinning, and finish coating the circuits of the board. Hot-air solder leveling (HASL), the most common method of finishing is one of the main sources of hazardous lead-bearing wastes in traditional PWB manufacturing. The development of a safer finishing method will lead to employee health and environmental benefits. In addition, there is a production advantage to eliminating HASL, for it provides a fairly uneven surface that is problematic for mounting very small components.

In this project, we developed "single-bath electroplating" as a potential HASL replacement technology for many applications. Single-bath electroplating involves alternating deposition of one or the other metal component of a bimetal bath, through control of plating potential and mass transport. It employs a nickel layer as both etch resist and finish coat and has the potential for lowering environmental and human-health risks associated with PWB manufacture-while at the same time reconfiguring the process for greater efficiency and profitability. 
During FY2000, for the PWB application developed in this project, we adapted techniques from layered electroforming methods that are used to build up copper-nickel composite materials of high tensile strength. These materials typically have many alternating, extremely thin layers of each metal. We altered the electroforming process parameters so that we could deposit the thicker layers of copper required for PWB circuitry.

The single-bath process generates copper deposits from a very dilute solution of copper ions (0.05-0.1 M), versus $2.0 \mathrm{M}$ for traditional PWB applications. In our single-bath approach, nickel concentrations are an order of magnitude greater than those of copper, and special complexing agents are used to modify reduction potentials. Solution $\mathrm{pH}$ is also controlled very closely. Amperometric manipulation is performed concurrently with agitation variations to insure the deposition of distinct layers of copper and nickel. Copper thicknesses on the order of 12 microns (0.0005") and nickel thicknesses of 1 micron (0.00004") are achieved by this approach.

Single-bath electroplating is applied to PWB fabrication as follows. Copper is plated first, to the desired thickness of the PWB's circuitry - typically 12 microns (0.0005"). Next, a nickel layer is deposited as an etch resist to protect copper circuitry. The etch-resist layer is left in place rather than stripped (as tin and tin/lead etch resists generally are) and serves as a finish coat for the PWB, onto which components are soldered. Our analyses demonstrated that this nickel layer, which contains a significant percentage of copper because of the chemistry of the process, provides a good solderable surface.

Our process (1) meets PWB-manufacturing requirements for level, bright, durable deposits and for a solderable nickel layer; (2) eliminates a costly, labor-intensive operation that also generates significant hazardous waste, because our nickel etch-resist layer does not have to stripped and discarded; (3) eliminates use of highly toxic lead-bearing materials from several PWB manufacturing steps, including etch-resist deposition, finish coating, and tinning; and (4) combines several fabrication steps into one tank, by depositing either copper (for circuitry) or nickel (for an etch-resistant finish) from the same bath. This can reduce equipment requirements as well as the floor space "footprint" needed for manufacturing PWBs. In many 
shops, footprint reductions can have a significant impact on reducing production costs.

A patent on single-bath electroplating has been applied for (LLNL Patent Office File Number IL10598), and an industry sponsor, Shipley Company (a division of Rohm and Haas) is funding continued development of the technology. 